\title{
Pelatihan Pembuatan Mesin Penetas Telur Puyuh Otomatis Untuk Meningkatkan Pendapatan Masyarakat di Kelurahan Sukarami Bengkulu
}

\author{
Yovan Witanto $^{1 *}$, Adhadi Kurniawan ${ }^{2}$, Anizar Indriani ${ }^{3}$ \\ ${ }^{1}$ Program Studi Teknik Mesin, Fakultas Teknik, Universitas Bengkulu \\ ${ }^{23}$ Program Studi Teknik Elektro, Fakultas Teknik, Universitas Bengkulu \\ E-mail: *yovan@unib.ac.id
}

\begin{tabular}{l}
\hline Article History: \\
Received: Oktober \\
Revised: Oktober \\
Accepted: November \\
Available online: Desember \\
\\
Kata Kunci: \\
Mikrokontroler, Mesin Penetas \\
Telur Otomatis, \\
SMS, Telur Burung Puyuh,
\end{tabular}

Article History:

Revised: Oktober

Accepted: November

Available online: Desember

Kata Kunci:

Mikrokontroler, Mesin Penetas

SMS, Telur Burung Puyuh,

\begin{abstract}
Abstrak:
Tujuan pengabdian kepada masyarakat ini adalah pelatihan pembuatan mesin penetas telur puyuh otomatis untuk meningkatkan pendapatan masyarakat di kelurahan Sukarami, Bengkulu. Khalayak sasaran pelatihan adalah masyarakat Kelurahan Sukarami khususnya peternak burung puyuh. Pengabdian kepada masyarakat berbasis Ipteks ini akan dilakukan alih teknologi otomasi melalui pelatihan perencanaan, pembuatan dan penggunaan mesin penetas telur otomatis berbasis SMS dengan memanfaatkan Mikrokontroler. Materi pelatihan disampaikan secara online lewat youtube, kemudian dilakukan kunjungan untuk ujicoba perakitan dan penggunaan alat di lokasi. Hasil kegiatan menunjukkan bahwa tingkat kepuasan peserta sangat tinggi. Permasalahan yang dihadapi mitra dapat diatasi dengan menggunakan alat penetas telur berbasis sms ini. Waktu mereka yang selama ini terbuang dapat di atasi dengan info sms yang mereka terima dari alat ini. Dengan demikian kegiatan pelatihan ini berhasil. Waktu yang selama ini terbuang untuk menunggui proses penetasan telur, dapat digunakan untuk bekerja di tempat lain. Dengan demikian pendapatan meningkat.
\end{abstract}




\section{Pendahuluan}

Penerapan teknologi otomasi dapat dilihat pada bidang industri, manufaktur, pertanian/perkebunan/peternakan, perikanan dan lainnya (Andria et al., 2017) (Hendra et al., 2016) (Indriani et al., 2016) yang sangat membantu mengurangi waktu produksi, meningkatkan kualitas dan produktifitas, menjamin higienis proses dan mengurangi efek lingkungan. Penerapan teknologi otomasi ini sangat membantu mengurangi kebutuhan akan tenaga kerja serta area pemantauan yang semakin luas. Satu penerapan teknologi otomasi adalah pada proses penetasan telur Puyuh memanfaatkan mikrokontroler untuk mengatur sistem gerak dan memberi informasi kondisi telur melalui SMS (handphone). Puyuh merupakan kelompok unggas yang mudah dikembangkan dalam waktu yang relatif cepat, area yang sempit, dan modal yang kecil. Puyuh dapat digunakan sebagai sumber protein hewani berupa telur dan daging. Telur Puyuh dan daging didapatkan dari budidaya ternak Puyuh yang terus berkembang seiring dengan tingkat kebutuhan masyarakat (Handayani et al., 2013). Proses penetasan telur Puyuh dapat dilakukan secara alamiah dan menggunakan mesin tetas. Dalam proses penetasan telur Puyuh secara alamiah setiap induk hanya mampu mengerami 5 butir telur (Rizki et al., 2018) Sementara penetasan dengan mesin tetas dapat mengerami lebih banyak telur tetapi masih memberikan hasil yang kurang maksimal karena belum adanya sistem kontrol gerak untuk memutar posisi telur Puyuh. Hal yang harus diperhatikan dalam mesin tetas adalah pengaruh level suhu mesin tetas (Neonnub et al., 2020).

Hasil penelitian memperlihatkan level suhu mesin tetas $37,5^{\circ} \mathrm{C}$ selama masa inkubasi menghasilkan daya dan bobot tetas DOQ puyuh Padjadjaran yang optimal. Mesin penetas telur puyuh telah banyak digunakan oleh peternak telur Puyuh. Dimana kerja mesin penetas telur puyuh masih manual dan sederhana yaitu dengan memanfaatkan lampu pijar 100 watt dan dinding boks pengering dari papan. Selama ini proses penetasan telur masih membutuhkan tenaga manusia dalam memantau dan mengolah telur puyuh. Dengan menggunakan mesin penetas otomatis ini penggunaan tenaga manusia dapat dikurangi. Mesin penetas otomatis dapat bekerja sendiri dengan pengaturan temperatur pemanasan yang konstan. Proses pengubahan posisi 
dudukan telur juga dapat dilakukan secara otomatis. Penggantian posisi telur puyuh mempengaruhi penetasan. (Sujana et al., 2019) mulai hari penetasan ke 3 telur diputar 3 kali sehari dan pada hari ke 14 pemutaran telur dihentikan. Hari ke 18 penetasan berakhir. Potensi daerah Kelurahan Sukarami Kota Bengkulu yang masih luas banyak dimanfaatkan oleh masyarakat untuk beternak Puyuh seiring dengan permintaan daging Puyuh yang terus meningkat.

Peningkatan produktivitas Puyuh harus memperhatikan pemilihan bibit, pengaturan pakan, tempat pemeliharaan, sanitasi, kesehatan dan lainnya. Pengelolaan ternak Puyuh masih dilakukan secara manual dan menggunakan mesin penetas konvensional dimana hasil yang diperoleh masih kurang optimal (1000 telur yang akan ditetaskan, hanya menetas sekitar 700-900 telur). Hal ini disebabkan oleh belum adanya sistem pengaturan temperatur, penggantian posisi telur Puyuh yang masih manual, tidak adanya pengecekan kondisi telur serta proses penetasan yang kurang bersih (higiensi). Keberhasilan proses penetasan telur dipengaruhi oleh temperature ruangan, kelembaban, pemanasan yang merata pada setiap telur, kebersihan lingkungan mesin penetas dan lainnya. Untuk meningkatkan produktifitas, dilakukan pembuatan mesin penetas otomatis berbasis mikrokontroler (Jasa, 2006) (Nasrudin, 2007). Jasa dan nasrudin mendesain mesin penetas telur otomatis dengan sistem pengaturan temperatur. Sistem kendali suhu, kelembaban udara mesin penetas dan pemutar telur dapat juga di lakukan dengan menggunakan PLC.

Mesin penetas telur ini fokus pada pengaturan suhu dan kelembaban menggunakan PLC (Programmable Logic Controller), dan menguji unjuk kerja komponen dan sistem kendali hasil rancang bangun di laboratorium Induk (Winarto et al., 2008). Pengabdian masyarakat penerapan IPTEKS ini yakni pelatihan pemanfaatan teknologi otomasi pada proses penetasan telur Puyuh. Pelatihan yang diberikan meliputi pengenalan komponen mesin penetas otomatis berbasis SMS. Juga dikenalkan prinsip kerja sistem kontrol, perencanaan dan pembuatan rangkaian serta mesin penetas telur puyuh sistem otomatis. Di samping itu akan dikenalkan cara kerja dan penggunaan mesin tersebut. Alih teknologi yang akan dilakukan pada pengabdian masyarakat ini yaitu, pemanfaatan mesin penetas telur Puyuh otomatis untuk sistem kontrol 
temperatur dan gerak dudukan/loyang penetas telur. Dengan demikian diharapkan dapat meningkatkan produktifitas peternak telur Puyuh, sehingga pendapatan masyarakat meningkat. Disamping itu juga sekaligus menjaga ketahanan pangan terutama ketersediaan daging Puyuh sebagai sumber nutrisi bagi masyarakat. Selain itu, alih teknologi ini dilakukan karena adanya permintaan dari masyarakat yang membutuhkan pelatihan pembuatan mesin penetas telur Puyuh yang murah, mudah dibuat dan proses penetasan yang cepat. Evaluasi dari proses alih teknologi ini adalah dengan cara mengukur kemampuan peserta dalam merakit dan mengoperasikan alat penetas telur otomastis ini. Untuk desain mesin penetas pada pengabdian ini mengkombinasikan sistem kontrol temperatur, kelembaban, posisi dudukan telur dan pendeteksian proses penetasan melalui pesan pendek (SMS). Dengan desain ini kondisi penetasan telur Puyuh dapat dilakukan setiap saat dan dimanapun melalui handphone (SMS). Sehingga waktu peternak tidak lagi terbuang hanya untuk mengurusi proses penetasan telur puyuh

\section{Metode}

Kegiatan pengabdian ini dilaksanakan tanggal 21 September 2020, bertempat di Jalan Kebun Indah 6 RT 44 RW 09 Kelurahan Sukarami Kecamatan Selebar Kota Bengkulu. Kegiatan ini melibatkan 5 orang peserta, yakni peternak puyuh produktif. Tahap pertama, pembuatan kotak mesin penetas telur puyuh otomatis dan merakit rangkaian elektronik sesuai dengan desain rancangan awal. Kemudian akan direkam ke dalam video yang diupload di yuotube https://youtu.be/nRH1fMGvOdw, sebagai tutorial pembuatan kotak dan pengenalan komponen elektronika mesin penetas telur puyuh otomatis. Setelah peralatan dan video tutorial siap, dilakukan survey lapangan guna mengetahui kondisi khalayak sasaran dan penjajagan awal untuk penentuan lokasi pengabdian dan kesepakatan diadakan kegiatan ini. Tahap kedua diadakan kunjungan ke lokasi peternak puyuh, untuk dilakukan evaluasi hasil pelatihan lewat youtube. Kemudian peserta akan dikenalkan peralatan secara langsung dan didemokan cara merakitnya. Sistem tahapan pelaksanaan secara garis besar ditunjukkan pada Gambar 1 berikut. 


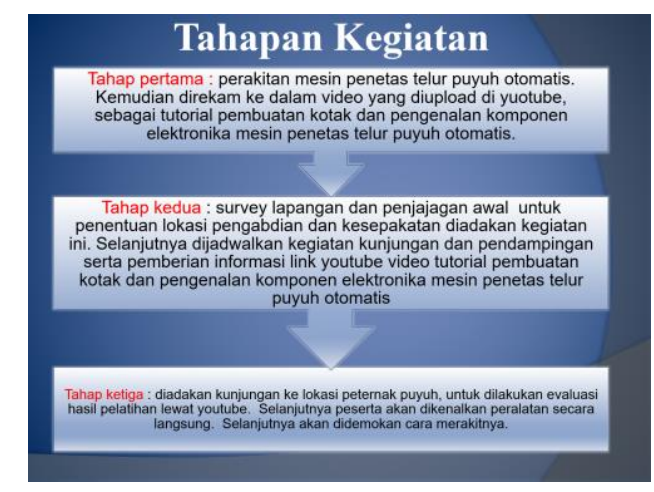

Gambar 1. Tahapan kegiatan pengabdian

Setelah kegiatan selesai peserta diminta mengisi kuisioner. Kuisioner tersebut dibagikan kepada 5 responden dengan jumlah pertanyaan 13, untuk mengevaluasi tentang materi pelatihan, penyajian materi, manfaat dan kepuasan pelatihan bagi peserta serta fasilitas pelatihan. Selanjutnya akan dianalisis dengan menggunakan metode skala Likert (Suwandi et al., 2019) dengan kriteria seperti terlihat pada tabel 1

Tabel 1. Pemberian skor

\begin{tabular}{clcc}
\hline \multicolumn{4}{c}{ PEMBERIAN SKOR } \\
\hline Nomer & Jawaban & Kode & Bobot \\
\hline 1 & Sangat Puas & SP & 4 \\
\hline 2 & Puas & P & 3 \\
\hline 3 & Kurang puas & KP & 2 \\
\hline 4 & Sangat Kurang Puas & SKP & 1 \\
\hline
\end{tabular}

\section{Hasil}

Kegiatan ini diawali dengan penjajagan awal, yakni pertemuan dengan bapak lurah untuk penentuan lokasi pengabdian dan kesepakatan diadakan kegiatan ini. Kegiatan ini menghasilkan kesepakatan bahwa peserta kegiatan adalah lima warga peserta peternak puyuh yang ada di RT 44, RW 09. Lima peserta tersebut diharapkan dapat melakukan pelatihan lanjutan kepada warga disekitar tempat tinggal mereka. Kegiatan pelatihan akan dilaksanakan dirumah bapak Rustam Ahmadi. Kegiatan diawali dengan membagikan link video youtube https://youtu.be/nRH1fMGvOdw tentang cara membuat kotak 
mesin penetas telur puyuh otomatis dan merakit rangkaian elektronik. Kegiatan berikutnya merupakan kegiatan kunjungan yang telah diagendakan. Kegiatan ini dilaksanakan dirumah bapak Rustam Ahmadi. Kegiatan diawali dengan pembukaan, yang dilakukan oleh bapak Rustam Ahmadi, mewakili Bapak lurah Sukarami yang berhalangan hadir. Kemudian dilanjutkan dengan sesi pertama yakni pengenalan dan perakitan alat penetas telur puyuh otomatis yang dilakukan oleh ketua pengabdian Adhadi Kurniawan dan dilanjutkan dengan sesi kedua pengenalan komponen mekanik dari mesin penetas telur yang dilakukan oleh anggota pengabdian, Yovan Witanto (Gambar 2).

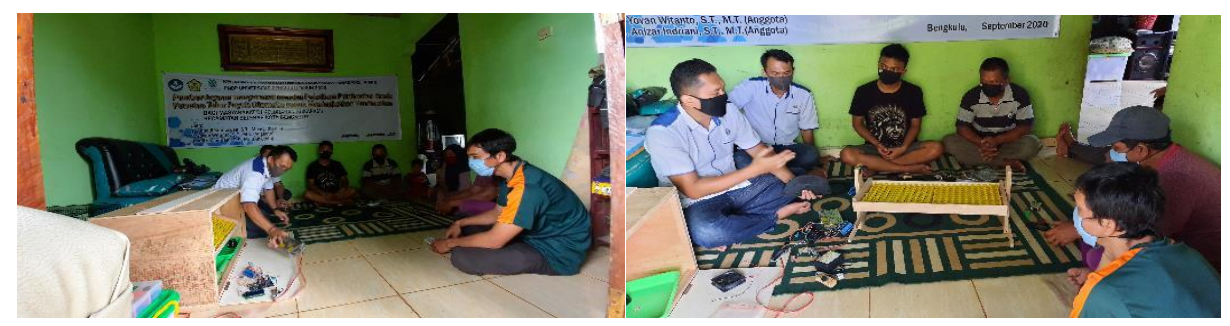

Gambar 2. Pengenalan dan perakitan alat penetas telur puyuh otomatis

Kegiatan selanjutnya adalah uji coba perakitan dan pengoperasian alat oleh salah satu peserta yakni Bayu. Kegiatan dilakukan dengan demo pengoperasian alat. Para peserta yang telah berhasil merakit peralatan tersebut diajarkan untuk menggunakan alat dengan benar (Gambar 4)

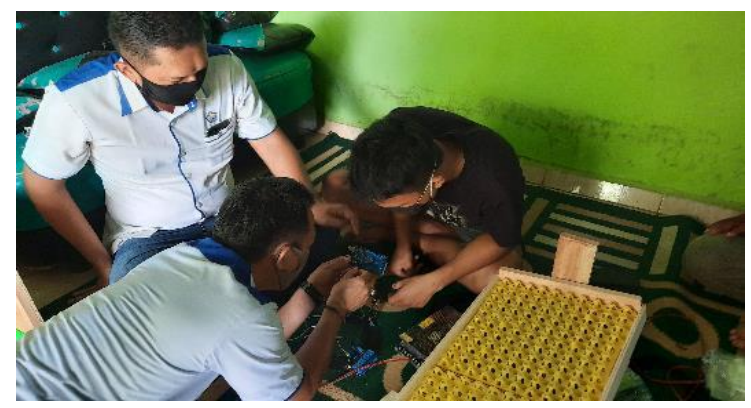

Gambar 4. Uji coba perakitan dan pengoperasian alat oleh peserta.

Setelah diajarkan mengunakan alat, peserta diminta untuk mencoba secara bergantian. Hasil uji coba penunjukkan bahwa penggunaan alat tersebut lebih praktis dalam menetaskan telur puyuh. Dengan menggunakan alat tersebut, mereka bisa melakukan kegiatan untuk mencari nafkah lainnya 
yang tentu saja akan meningkatkan pendapatan mereka. Setelah praktek uji coba alat, peserta diminta untuk memberikan tanggapannya tentang alat yang telah mereka rakit dan uji cobakan dengan mengisi kuisioner seperti terlihat pada tabel 2 .

Tabel 2. Hasil Angket Evaluasi Kegiatan Pengabdian

\begin{tabular}{ccccccccccccccc}
\hline \multirow{2}{*}{$\begin{array}{c}\text { No } \\
\text { Responden }\end{array}$} & \multicolumn{10}{c}{ Kode Soal } \\
\cline { 2 - 14 } & $\mathbf{S}_{\mathbf{1}}$ & $\mathbf{S}_{\mathbf{2}}$ & $\mathbf{S}_{\mathbf{3}}$ & $\mathbf{S}_{\mathbf{4}}$ & $\mathbf{S}_{\mathbf{5}}$ & $\mathbf{S}_{\mathbf{6}}$ & $\mathbf{S}_{\mathbf{7}}$ & $\mathbf{S}_{\mathbf{8}}$ & $\mathbf{S}_{\mathbf{9}}$ & $\mathbf{S}_{\mathbf{1 0}}$ & $\mathbf{S}_{\mathbf{1 1}}$ & $\mathbf{S}_{\mathbf{1 2}}$ & $\mathbf{S}_{\mathbf{1 3}}$ & $\begin{array}{c}\text { Total } \\
\text { Skor }\end{array}$ \\
\hline 1 & 4 & 3 & 4 & 4 & 3 & 4 & 4 & 3 & 3 & 3 & 3 & 3 & 3 & 44 \\
\hline 2 & 4 & 3 & 4 & 4 & 3 & 4 & 4 & 3 & 4 & 3 & 3 & 3 & 3 & 45 \\
\hline 3 & 4 & 3 & 3 & 4 & 4 & 3 & 3 & 3 & 4 & 4 & 3 & 4 & 4 & 45 \\
\hline 4 & 4 & 4 & 3 & 4 & 4 & 3 & 4 & 3 & 4 & 3 & 4 & 4 & 4 & 48 \\
\hline 5 & 3 & 4 & 4 & 3 & 3 & 3 & 3 & 4 & 3 & 3 & 4 & 3 & 3 & 43 \\
\hline
\end{tabular}

Langkah selanjutnya adalah mencari hasil Skoring menggunakan skala Likert. Berdasarkan Tabel 1. dapat diketahui hasil dari persentase tingkat kepuasan tentang materi pelatihan, penyajian materi, manfaat yang didapat peserta selama pelatihan serta fasilitas pelatihan seperti terlihat pada gambar 5 .

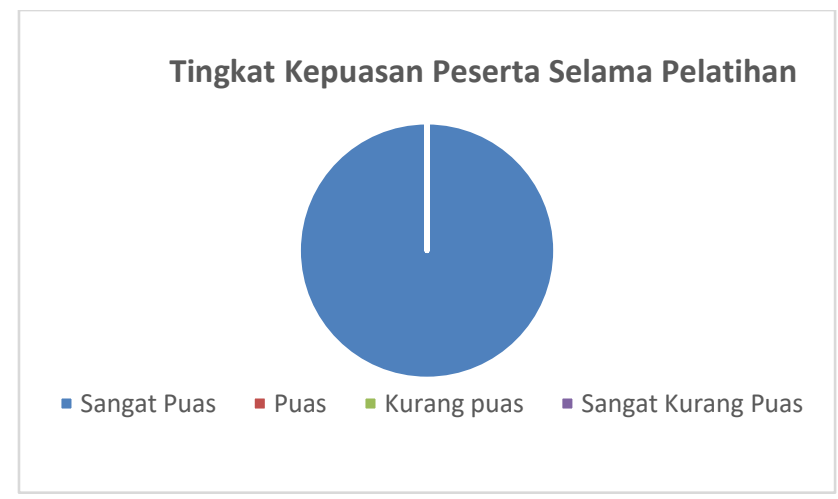

Gambar 5. Grafik Tingkat kepuasan peserta selama pelatihan

Grafik yang terlihat pada gambar 5, menunjukkan bahwa peserta pelatihan sangat puas terhadap pelatihan ini. 


\section{Diskusi}

Hasil kegiatan pengabdian pada masyarakat ini menunjukkan bahwa peserta sangat puas terhadap pelatihan ini. Permasalahan yang dihadapi mitra yakni belum adanya sistem pengaturan temperatur, penggantian posisi telur puyuh yang masih manual, dan tidak adanya pengecekan kondisi telur dapat diatasi dengan menggunakan alat penetas telur berbasis sms ini. Temuan yang dijumpai selama pengabdian ini antara lain yakni waktu peternak puyuh selama ini banyak terbuang hanya untuk menunggui proses penetasan telur. Proses pemutaran posisi telur dan pengaturan suhu agar stabil sangat menyita banyak waktu mereka. Mesin penetas telur yang dilengkapi info sms yang mereka terima dari alat ini dapat membantu mengurangi waktu yang selama ini terbuang hanya untuk menunggui penetasan. Dengan demikian kegiatan pelatihan ini berhasil. Temuan lain yang dijumpai dari proses pengabdian adalah listrik kadang tidak setabil, sehingga waktu penetasan menjadi lama dan bahkan gagal. Untuk itu Keberlanjutan dari kegiatan ini dengan pelatihan pembuatan alat penetas telur menggunakan energi alternatif. Kegiatan diakhiri dengan serah terima alat kepada peserta pengabdian. Proses serah terima alat pengabdian dapat dilihat pada gambar 6 .

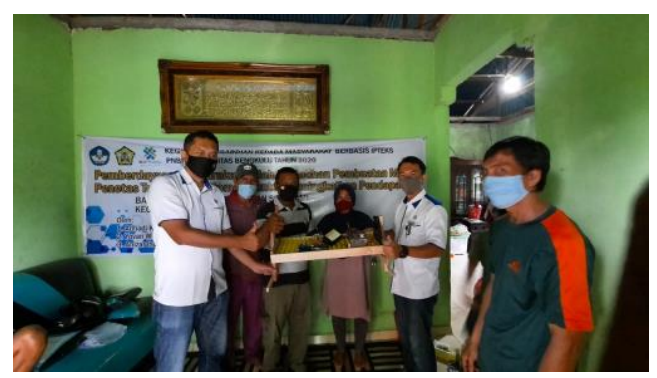

Gambar 6. Serah terima alat pengabdian

Peserta diberikan peralatan lengkap, dan jika ingin dimodif maka akan dilakukan pendampingan. Alat yang telah diserah-terimakan kepada peserta langsung mereka gunakan untuk penetasan telur puyuh. 


\section{Kesimpulan}

Hasil kegiatan pengabdian pada masyarakat ini menunjukkan bahwa peserta sangat puas terhadap pelatihan ini. Permasalahan yang dihadapi mitra dapat diatasi dengan menggunakan alat penetas telur berbasis sms ini. Waktu mereka yang selama ini terbuang hanya untuk menunggui penetasan telur dapat diatasi dengan info sms yang mereka terima dari alat ini. Dengan demikian kegiatan pelatihan ini berhasil. Waktu yang selama ini terbuang untuk menunggui proses penetasan telur, dapat digunakan untuk bekerja di tempat lain. Dengan demikian pendapatan meningkat. Keberlanjutan dari kegiatan ini sangat mereka harapkan. Yakni dengan pembuatan alat penetas telur tanpa menggunakan energi listrik dari PLN

\section{Pengakuan/Acknowledgements}

Kegiatan PPM ini telah dilaksanakan dengan baik. Sehubungan dengan itu pada kesempatan ini kami menyampaikan ucapan terima kasih kepada pihak yang turut membantu yaitu:

1. Pihak Lembaga Pengabdian Pada Masyarakat Universitas Bengkulu yang telah mendanai kegiatan ini melalui DIPA UNIVERSITAS BENGKULU Nomor: SP.DIPA-023.017.2.677529/2020. Tanggal 27 Desember 2019 dengan Surat Perjanjian Nomor 2375/UN30.15/AM/2020.

2. Mitra Universitas Bengkulu yang telah banyak membantu pelaksanaan kegiatan hingga dapat terlaksana secara baik.

\section{Daftar Referensi}

Andria, F., Effendi, E. M., \& Maesya, A. (2017). Otomatisasi Mesin Tetas Telur Puyuh Untuk Optimasi Pembibitan, Peningkatan Produksi Dan Pemasaran Bagi Peternak Puyuh. Qardhul Hasan: Media Pengabdian Kepada Masyarakat, 3(2), 107. https://doi.org/10.30997/qh.v3i2.946 Handayani, I., Tana, S., \& Saraswati, T. R. (2013). PANJANG DAN BOBOT SALURAN REPRODUKSI PUYUH BETINA ( Coturnix coturnix japonica ) SETELAH PEMBERIAN TEPUNG KUNYIT ( Curcuma longa $\mathrm{L} \quad$.). Jurnal Biologi, 2(3), 17-24. https://ejournal3.undip.ac.id/index.php/biologi/article/view/19149 
Hendra, Indriani, A., Hernadewita, \& Rizal, Y. (2016). Assembly Programmable Logic Control (PLC) in the Rotary Dryer Machine for Processing Waste Liquid System. Applied Mechanics and Materials, 842 , 319-323.

https://doi.org/10.4028/www.scientific.net/AMM.842.319

Indriani, A., Hendra, \& Witanto, Y. (2016). Error of Assembly Microcontroller Arduino Mega and ATmega in the Control of Temperature for Heating and Cooling System. Applied Mechanics and Materials, 842 , 324-328. https://doi.org/10.4028/www.scientific.net/amm.842.324

Jasa, L. (2006). Pemanfaatan Mikrokontroler Atmega163 Pada Prototipe Mesin Penetasan Telur Ayam. Majalah Ilmiah Teknologi Elektro, 5(1), 30-36. https://ojs.unud.ac.id/index.php/JTE/article/view/222

Nasrudin, M. (2007). Penentuan Suhu Pada Ruangan Penetasan Telur. Komunikasi Penelitian-MIPA, 1(1), 30-33. http://repository.usu.ac.id/handle/123456789/21205

Neonnub, J., Adriani, L., \& Setiawan, I. (2020). Pengaruh Level Suhu Mesin Tetas Terhadap Daya Tetas dan Bobot Tetas Telur Puyuh Padjadjaran. Jurnal Ilmu Ternak Universitas Padjadjaran, 19(2), 1. https://doi.org/10.24198/jit.v19i2.23605

Rizki, I., Kustanto, K., \& Siswanti, S. (2018). Sistem Monitoring Pengontrol Suhu Dan Intensitas Cahaya Pada Penetas Telur Puyuh. Jurnal Teknologi Informasi Dan Komunikasi (TIKomSiN), 6(1), 45-50. https://doi.org/10.30646/tikomsin.v6i1.349

Sujana, E., Widjastuti, T., Setiawan, I., \& Anang, A. (2019). Karakteristik Hasil Penetasan Puyuh Pedaging Malon Dan Jepang Terseleksi Generasi Ke Lima. Jurnal Ilmu Ternak Universitas Padjadjaran, 18(2), 110-114. https://doi.org/10.24198/jit.v18i2.18287

Suwandi, E., Imansyah, F. H., \& Dasril, H. (2019). Analisis Tingkat Kepuasan Menggunakan Skala Likert pada Layanan Speedy yang Bermigrasi ke Indihome. Jurnal Teknik Elektro, 1(1). https://jurnal.untan.ac.id/index.php/jteuntan/article/view/31191

Winarto, Syah, B., \& Harmen. (2008). Rancang Bangun Sistem Kendali Suhu Dan Kelembaban Udara. ELECTRICIAN, 2(1), 23-32. https://doi.org/https://doi.org/10.23960/elc.v2n1.11 